\title{
Faktor-faktor yang berhubungan dengan praktik pemberian ASI eksklusif pada bayi usia 0-6 bulan di Kabupaten Timor Tengah Selatan
}

Factors associated with exclusive breastfeeding practice among infants aged 0-6 months in Timor Tengah Selatan District

\author{
Ari Tri Astuti ${ }^{1}$, Hamam Hadi ${ }^{2}$, Madarina Julia ${ }^{3}$ \\ ${ }^{1}$ Program Studi S1 Ilmu Gizi, Fakultas Ilmu Kesehatan, Universitas Respati Yogyakarta \\ ${ }^{2}$ Universitas Alma Ata, Yogyakarta \\ ${ }^{3}$ Departemen Ilmu Kesehatan Anak, Fakultas Kedokteran, Kesehatan Masyarakat, dan Keperawatan Universitas Gadjah Mada, Yogyakarta
}

\begin{abstract}
Background: National Basic Health Research of 2018 in Indonesia indicated only 37.3\% of infants aged 0-5 months were exclusively breastfeed. East Nusa Tenggara is one of the provinces with the lowest exclusive breastfeeding coverage in 2018. A survey in Timor Tengah Selatan district showed that exclusive breastfeeding also decreased from 2015 and 2016 which was $63.3 \%$ to $59.1 \%$. Several factors have been known to be associated with exclusive breastfeeding practice, such as mother's education and occupation, household expenditure, antenatal care history, and husband's support. Objective: To identify factors associated with exclusive breastfeeding practice among infants aged 0-6 months in Timor Selatan District, East Nusa Tenggara province. Methods: An observational study with a cross-sectional design was conducted among 155 lactating mothers of infants aged 0-6 months. The secondary data from "Study on behavioral analysis and food consumption/dietary practices among children under five, elementary school-age children, pregnant and lactating mother in Timor Tengah Selatan District of East Nusa Tenggara Province” were used. Raw data were collected in July 2012 in Amanuban Barat and Kie subdistrict, Timor Tengah Selatan. The data were analyzed in July-December 2014 using Chi-Square and logistic regression test. Results: Household expenditure, antenatal care location, and subdistrict associated with exclusive breastfeeding practice $(p<0.05)$. Lactating mothers who did prenatal care at primary health care/primary health care satellite/hospital were 3.51 times more likely to breastfeed exclusively $(O R=3.51 ; 95 \%$ CI: 1.03-11.9). Household expenditure (OR=0.27; 95\%CI: 0.09-0.84) and subdistrict (OR=0.19; 95\%CI: 0.05-0.71) had protective effect. Conclusions: A significant association was found between exclusive breastfeeding practice and household expenditure, antenatal care location, and the subdistrict in Timor Tengah Selatan district.
\end{abstract}

KEYWORDS: antenatal care history; exclusive breastfeeding; household expenditure; husband's support; mother's education; mother's occupation

\begin{abstract}
ABSTRAK
Latar belakang: Riskesdas 2018 menyatakan bahwa persentase menyusui eksklusif pada bayi yang berusia 0-5 bulan di Indonesia hanya 37,3\%. Nusa Tenggara Timur (NTT) merupakan salah satu provinsi dengan cakupan ASI eksklusif terendah tahun 2018. Pemberian ASI eksklusif di Kabupaten Timor Tengah Selatan, NTT juga mengalami penurunan dari tahun 2015 dan 2016 yaitu 63,3\% menjadi 59,1\%. Praktik pemberian ASI eksklusif diduga dapat dipengaruhi oleh banyak faktor seperti pendidikan dan pekerjaan ibu, pengeluaran rumah tangga, riwayat pemeriksaan kehamilan, serta dukungan suami. Tujuan: Penelitian ini bertujuan untuk mengetahui faktor-faktor yang berhubungan dengan praktik pemberian ASI eksklusif pada bayi usia 0-6 bulan di Kabupaten Timor Tengah Selatan, Nusa Tenggara Timur. Metode: Penelitian observasional dengan rancangan cross sectional ini menggunakan data sekunder dari penelitian "Analisis perilaku dan konsumsi makanan/praktik diet pada anak di bawah usia lima tahun, anak usia sekolah dasar, ibu hamil, dan ibu menyusui di Kabupaten Timor Tengah Selatan, Provinsi Nusa Tenggara Timur”. Pengambilan data mentah dilakukan pada Juli 2012 di Kecamatan Amanuban Barat dan Kie. Penggunaan dan pengolahan data sekunder pada Juli-Desember 2014. Subjek penelitian adalah ibu menyusui yang mempunyai bayi berusia 0-6 bulan. Besar sampel dalam penelitian ini adalah 155 ibu menyusui. Analisis data menggunakan uji Chi-Square dan regresi logistik. Hasil: Pengeluaran rumah tangga, tempat pemeriksaan kehamilan, dan asal kecamatan berhubungan dengan praktik pemberian ASI eksklusif ( $p<0,05$ ). Ibu menyusui
\end{abstract}

Korespondensi: Ari Tri Astuti, Program Studi S1 Ilmu Gizi, Fakultas Ilmu Kesehatan, Universitas Respati Yogyakarta, J1 Raya Tajem Km 1,5 Maguwoharjo, Depok, Kabupaten Sleman, Provinsi DIY, Indonesia, e-mail: aritriastuti@respati.ac.id 
yang memeriksakan kehamilan di puskesmas/pustu/rumah sakit mempunyai kemungkinan 3,51 kali lebih tinggi untuk memberikan ASI eksklusif $(\mathrm{OR}=3,51 ; 95 \% \mathrm{CI}$ : 1,03- 11,9). Faktor pengeluaran rumah tangga (OR=0,27; 95\%CI: 0,09-0,84) dan daerah asal kecamatan subjek $(\mathrm{OR}=0,19 ; 95 \% \mathrm{CI}$ : 0,05-0,71) bersifat protektif. Simpulan: Pengeluaran rumah tangga, tempat pemeriksaan kehamilan, dan asal kecamatan berhubungan dengan praktik pemberian ASI eksklusif di Kabupaten Timor Tengah Selatan.

KATA KUNCI: riwayat pemeriksaan kehamilan; ASI eksklusif; pengeluaran rumah tangga; dukungan suami; pendidikan ibu; pekerjaan ibu

\section{PENDAHULUAN}

Pemberian air susu ibu (ASI) pada bayi, terutama pemberian kolostrum dapat melindungi bayi dari risiko kematian akibat diare dan infeksi saluran pernapasan akut (1-3). Bayi yang dahulunya diberi ASI cenderung memiliki tekanan darah, kadar kolesterol total, serta prevalensi obesitas dan diabetes mellitus tipe 2 yang lebih rendah daripada bayi yang dahulu tidak diberi ASI (4). Ibu yang menyusui juga berisiko lebih rendah terkena kanker payudara dan defisiensi zat besi. Menyusui juga dapat meningkatkan jarak kelahiran dengan anak berikutnya (5).

Riset Kesehatan Dasar (Riskesdas) 2018 menunjukkan bahwa persentase menyusui eksklusif pada bayi yang berusia $0-5$ bulan adalah $37,3 \%$. Provinsi Nusa Tenggara Timur (NTT) menempati provinsi terendah kedua dalam pemberian ASI eksklusif dibandingkan 34 provinsi di Indonesia dan jauh sekali dari angka nasional (6). Data dari Dinas Kesehatan Kabupaten Timor Tengah Selatan tahun 2017 menunjukkan fluktuasi bayi yang mendapatkan ASI eksklusif. Pemberian ASI Ekslusif di Kabupaten Timor Tengah Selatan mengalami penurunan dari tahun 2012 sebesar 40,7\% menjadi 22,6\% pada tahun 2013. Tahun 2014 meningkat lagi menjadi 76,6\%, sedangkan data terakhir tahun 2015 dan 2016 turun dari 63,3\% menjadi 59,1\% (7).

Praktik pemberian ASI oleh ibu menyusui dapat dipengaruhi oleh banyak faktor salah satunya adalah faktor sosial ekonomi dan demografi seperti pendidikan dan pengetahuan ibu (8-12), status pekerjaan ibu (8,12-14), dan kesejahteraan keluarga (15). Ibu yang mempunyai pendidikan lebih rendah berhubungan dengan keputusan untuk berhenti menyusui (9).

Selain faktor sosial ekonomi dan demografi tersebut, faktor dukungan kepada ibu untuk menyusui baik dari keluarga maupun petugas kesehatan juga dapat menentukan keberhasilan praktik menyusui $(8,10,13,14)$. Kunjungan ibu hamil ke tempat pelayanan kesehatan, pemeriksaan kehamilan dengan tenaga kesehatan seperti bidan atau dokter, serta pilihan tempat melahirkan juga dapat mempengaruhi praktik pemberian ASI $(10,14)$. Ibu yang melakukan kunjungan antenatal sebanyak empat kali atau lebih secara signifikan mempunyai kemungkinan untuk memberikan ASI eksklusif (14).

Dengan demikian, penelitian ini dilaksanakan untuk mengetahui hubungan faktor-faktor tersebut lebih lanjut, terutama di NTT yang tercatat sebagai provinsi kedua terendah dalam pemberian ASI eksklusif setelah Nusa Tenggara Barat (NTB) (6). Penelitian ini bertujuan untuk menentukan hubungan antara faktor-faktor yang berhubungan dengan praktik pemberian ASI ekslusif di Kabupaten Timor Tengah Selatan Provinsi NTT. Faktor yang dilihat adalah pendidikan ibu, pekerjaan ibu, pengeluaran rumah tangga, riwayat pemeriksaan kehamilan, dan dukungan suami.

\section{BAHAN DAN METODE}

Jenis penelitian ini adalah penelitian observasional dengan rancangan cross sectional. Data yang digunakan dalam penelitian ini merupakan data sekunder yang berasal dari penelitian yang berjudul "Analisis perilaku dan konsumsi makanan/praktik diet pada anak di bawah usia lima tahun, anak usia sekolah dasar, ibu hamil, dan ibu menyusui di Kabupaten Timor Tengah Selatan Provinsi Nusa Tenggara Timur, Indonesia" yang dilakukan oleh Alma Ata Centre for Healthy Life and Food (ACHEAF) dan United Nation World Food Program (UNWFP) (16). Cara pengambilan sampel untuk pengambilan data penelitian ACHEAF dan UNWFP (2013) dilakukan dengan tahapan teknik purposive sampling dan accidental sampling. Pengambilan dan pengolahan data sekunder yang diambil dari penelitian ACHEAF dan UNWFP ini dilakukan pada Juli-Desember 2014.

Data sekunder yang diambil meliputi pendidikan ibu, pekerjaan ibu, pengeluaran rumah tangga, riwayat pemeriksaan kehamilan (frekuensi kunjungan ke 
Puskesmas/tenaga kesehatan, tempat pemeriksaan kehamilan, dan tempat persalinan), serta dukungan suami. Sementara itu, data untuk variabel terikat dalam penelitian ini adalah praktik pemberian ASI eksklusif. Menurut World Health Organization (WHO), praktik pemberian ASI ekslusif adalah bayi diberikan ASI saja atau perahan ASI dan tidak diberikan makanan atau minuman lain, termasuk air putih, kecuali dari obatobatan, dan vitamin atau mineral tetes. Pendidikan dikategorikan tinggi jika tamat SMA/sederajat/lebih tinggi dan pendidikan rendah jika tidak tamat SD, tamat $\mathrm{SD} /$ sederajat, atau tamat $\mathrm{SMP} /$ sederajat. Ibu tidak bekerja artinya sebagai ibu rumah tangga yang tidak mempunyai pekerjaan tetap untuk mendapatkan nafkah/penghasilan sedangkan ibu bekerja berarti ibu mempunyai pekerjaan tetap untuk mendapatkan nafkah/ penghasilan. Pengeluaran rumah tangga dikategorikan berdasarkan upah minimum regional (UMR) Kabupaten Timor Tengah Selatan tahun 2012 sebesar Rp 925.000. Dukungan untuk ibu menyusui dikategorikan menjadi dua yaitu dukungan suami dan bukan suami yang artinya ibu mendapatkan dukungan untuk menyusui dari keluarga selain suami seperti dari ayah/ibu kandung, ayah/ibu mertua, dan anggota keluarga lainnya.

Data usia bayi, jenis kelamin bayi, usia ibu, usia suami, jumlah anak dalam keluarga, pendidikan suami, pekerjaan suami, dan asal kecamatan juga diambil dari penelitian ACHEAF tersebut (16). Penelitian dan penggunaan data sudah mendapatkan persetujuan dari ketua peneliti ACHEAF yang dibuktikan dengan surat pernyataan izin oleh ketua peneliti ACHEAF. Analisis statistik yang dilakukan adalah analisis univariat, bivariat Chi-Square, dan analisis multivariat regresi logistik.

\section{HASIL}

\section{Karakteristik ibu menyusui di Kecamatan Amanuban Barat dan Kie}

Subjek penelitian ini adalah 155 ibu menyusui yang mempunyai bayi berusia 0-6 bulan yang tercatat di Posyandu wilayah Kecamatan Amanuban Barat dan Kie. Para ibu menyusui tersebut berasal dari tujuh desa di Kecamatan Amanuban Barat dan tujuh desa di Kecamatan Kie. Rerata usia ibu adalah 27,8 $\pm 6,41$ tahun dengan rerata frekuensi kunjungan kehamilan ke petugas kesehatan sebanyak 5,29 $\pm 2,3$ kali. Rerata usia suami ibu 32,85 $\pm 8,18$ tahun dengan rerata pengeluaran rumah tangga bulan sebesar 548.996,8 \pm 483.860,8 rupiah. Rerata jumlah tanggungan anak sebesar 2,45 \pm 1,41 orang dengan jumlah minimal anak dalam rumah adalah satu orang dan maksimal tujuh orang. Rerata usia bayi 3,12 $\pm 1,57$ bulan dan sebagian besar berjenis kelamin perempuan (Tabel 1).

\section{Faktor-faktor yang berhubungan dengan pemberian ASI ekslusif}

Hasil pada Tabel 2 menunjukkan bahwa variabel pengeluaran rumah tangga setiap bulan, tempat pemeriksaan kehamilan, dan dukungan suami berhubungan signifikan dengan praktik pemberian ASI eksklusif $(\mathrm{p}<0,05)$. Hasil odd ratio (OR) menunjukkan bahwa variabel pengeluaran rumah tangga mempunyai efek protektif yaitu ibu dengan pengeluaran rumah tangga lebih besar dari UMR mempunyai kemungkinan 3,8 kali lebih rendah untuk memberikan ASI eksklusif $(\mathrm{OR}=0,26$; 95\%CI: 0,086-0,82).

Ibu yang memeriksakan kehamilannya di fasilitas pelayanan kesehatan seperti puskesmas/puskesmas pembantu (Pustu)/rumah sakit mempunyai kemungkinan 5,98 lebih besar untuk melakukan praktik pemberian ASI eksklusif daripada yang hanya memeriksakan kehamilannya kepada bidan $(\mathrm{OR}=5,98$; 95\% CI: 1,6220,71). Selain itu, ibu yang memperoleh dukung suami kemungkinan 2,51 lebih besar untuk melakukan praktik pemberian ASI eksklusif (OR 2,51; 95\% CI: 0,88-6,86) (Tabel 2).

\section{Hubung variabel yang diduga sebagai potential confounders dengan praktik pemberian ASI eksklusif}

Variabel yang diduga mempunyai potensi hubungan dengan praktik pemberian ASI eksklusif antara lain usia ibu, usia suami, pendidikan suami, pekerjaan suami, usia bayi, jenis kelamin bayi, jumlah anak dalam keluarga serta asal kecamatan. Berdasarkan hasil analisis dalam Tabel 3 menunjukkan bahwa ibu menyusui yang tinggal di Kecamatan Amanuban Barat mempunyai kemungkinan 6,67 kali lebih rendah untuk melakukan 
Tabel 1. Karakteristik ibu menyusui di Kecamatan Amanuban Barat dan Kie ( $n=155$ orang)

\begin{tabular}{|c|c|c|}
\hline Karakteristik & n & $\%$ \\
\hline \multicolumn{3}{|l|}{ ASI eksklusif } \\
\hline $\mathrm{Ya}$ & 132 & 85,16 \\
\hline Tidak & 23 & 14,84 \\
\hline \multicolumn{3}{|l|}{ Kecamatan } \\
\hline Amanuban & 87 & 56,13 \\
\hline Kie & 68 & 43,87 \\
\hline \multicolumn{3}{|l|}{ Usia ibu (tahun) } \\
\hline $20-<35$ & 123 & 79,35 \\
\hline$<20$ dan $\geq 35$ & 32 & 20,65 \\
\hline \multicolumn{3}{|l|}{ Pendidikan ibu } \\
\hline Tinggi & 47 & 30,32 \\
\hline Rendah & 108 & 69,68 \\
\hline \multicolumn{3}{|l|}{ Pekerjaan ibu } \\
\hline Tidak bekerja & 136 & 87,7 \\
\hline Bekerja & 19 & 12,26 \\
\hline \multicolumn{3}{|l|}{ Usia suami (tahun) } \\
\hline $25-<40$ & 104 & 67,10 \\
\hline$<25$ dan $\geq 40$ & 51 & 32,90 \\
\hline \multicolumn{3}{|l|}{ Pendidikan suami } \\
\hline Tinggi & 51 & 33,12 \\
\hline Rendah & 103 & 66,88 \\
\hline \multicolumn{3}{|l|}{ Pekerjaan suami } \\
\hline $\begin{array}{l}\text { Karyawan swasta/PNS/TNI/Polri/ } \\
\text { wiraswasta }\end{array}$ & 34 & 22,08 \\
\hline Petani/peternak/nelayan/buruh tani & 120 & 77,92 \\
\hline \multicolumn{3}{|l|}{ Usia bayi (bulan) } \\
\hline$<4$ & 92 & 59,35 \\
\hline$\geq 4$ & 63 & 40,65 \\
\hline \multicolumn{3}{|l|}{ Jenis kelamin bayi } \\
\hline Laki-laki & 77 & 49,68 \\
\hline Perempuan & 78 & 50,32 \\
\hline \multicolumn{3}{|l|}{ Jumlah anak dalam keluarga (orang) } \\
\hline$<3$ & 93 & 60,00 \\
\hline$\geq 3$ & 62 & 40,00 \\
\hline \multicolumn{3}{|c|}{ Pengeluaran rumah tangga/bulan dalam rupiah } \\
\hline$\geq$ upah minimum regional & 24 & 15,48 \\
\hline$<$ upah minimum regional & 131 & 84,52 \\
\hline \multicolumn{3}{|l|}{$\begin{array}{l}\text { Frekuensi kunjungan ke Puskesmas/tenaga } \\
\text { kesehatan } \\
\text { selama hamil }\end{array}$} \\
\hline$\geq 4$ kali & 121 & 78,06 \\
\hline$<4$ kali & 34 & 21,94 \\
\hline \multicolumn{3}{|l|}{ Tempat pemeriksaan kehamilan } \\
\hline Puskesmas/Pustu/RS & 139 & 89,68 \\
\hline Bidan & 16 & 10,32 \\
\hline \multicolumn{3}{|l|}{ Tempat persalinan } \\
\hline Puskesmas/BPS/RB/RS & 125 & 80,65 \\
\hline Rumah sendiri/dukun terlatih/lainnya & 30 & 19,35 \\
\hline \multicolumn{3}{|l|}{ Dukungan } \\
\hline Suami & 114 & 73,55 \\
\hline Bukan suami & 41 & 26,45 \\
\hline
\end{tabular}

praktik pemberian ASI eksklusif $(\mathrm{OR}=0,15 ; 95 \% \mathrm{CI}$ : $0,03-0,56$ ). Ibu menyusui yang mempunyai suami usia 20 sampai kurang dari 35 tahun mempunyai kemungkinan 2,6 kali lebih besar untuk melakukan praktik pemberian ASI eksklusif (OR=2,60; 95\%CI: 0,95-7,08).

\section{Analisis multivariat}

Hasil analisis regresi logistik secara konsisten dari model 1 sampai model 7 menunjukkan variabel asal kecamatan mempunyai hubungan yang signifikan $(\mathrm{p}<0,05)$. Selanjutnya, pada model ke 5, 6, dan 7, variabel tempat pemeriksaan kehamilan dan pengeluaran rumah tangga bersama dengan variabel asal kecamatan menunjukkan hubungan yang signifikan (Tabel 4). Berdasarkan kualitas model regresi logistik yang dinilai menggunakan uji goodness of fit (uji Hosmer dan Lemeshow), area under Receiver Operating Characteristic (ROC) curve, serta classification plot, ditentukan bahwa model 5 adalah yang paling sesuai. Pada model 5 regresi logistik diperoleh bahwa tempat pemeriksaan kehamilan dan pengeluaran rumah tangga bersama dengan variabel asal kecamatan menunjukkan hubungan yang signifikan. Pengeluaran rumah tangga dan daerah asal kecamatan subjek bersifat protektif.

Uji regresi logistik menunjukkan ibu menyusui yang mempunyai pengeluaran rumah tangga lebih tinggi dari UMR ( $\geq$ Rp 925.000) kemungkinan 3,7 kali lebih rendah untuk melakukan praktik pemberian ASI eksklusif (OR=0,27; 95\%CI: 0,09-0,84). Ibu menyusui yang berasal dari Kecamatan Amanuban Barat mempunyai kemungkinan 5,3 kali lebih rendah untuk melakukan praktik pemberian ASI eksklusif kepada bayinya (OR=0,19; 95\%CI: 0,05-0,71). Hasil regresi logistik menunjukkan bahwa ibu menyusui yang melakukan pemeriksaan kehamilan di puskesmas, puskesmas pembantu, atau rumah sakit mempunyai kemungkinan 3,51 kali lebih tinggi untuk melakukan praktik pemberian ASI eksklusif saat bayinya lahir daripada ibu yang melakukan pemeriksaan kehamilan pada bidan (OR=3,51; 95\%CI: 1,03-11,9). 
Tabel 2. Analisis faktor-faktor yang berhubungan dengan praktik pemberian ASI eksklusif

\begin{tabular}{|c|c|c|c|c|c|}
\hline \multirow[b]{2}{*}{ Variabel } & \multicolumn{2}{|c|}{ ASI eksklusif } & \multirow{2}{*}{$\begin{array}{c}\text { Jumlah } \\
\text { n (\%) }\end{array}$} & \multirow[b]{2}{*}{ OR $(95 \% \mathrm{CI})$} & \multirow[b]{2}{*}{$\mathbf{p}$} \\
\hline & $\begin{array}{c}\text { Ya } \\
\text { n (\%) }\end{array}$ & $\begin{array}{l}\text { Tidak } \\
\text { n (\%) }\end{array}$ & & & \\
\hline \multicolumn{6}{|l|}{ Pendidikan ibu } \\
\hline Tinggi & $37(78,72)$ & $10(21,28)$ & $47(100)$ & $0,51(0,19-1,42)$ & 0,14 \\
\hline Rendah & $95(87,96)$ & $13(12,04)$ & $108(100)$ & 1,00 & \\
\hline \multicolumn{6}{|l|}{ Pekerjaan ibu } \\
\hline Tidak bekerja & $117(86,03)$ & $19(13,97)$ & $136(100)$ & $1,64(0,36-5,92)$ & 0,49 \\
\hline Bekerja & $15(78,95)$ & $4(21,05)$ & $19(100)$ & 1,00 & \\
\hline \multicolumn{6}{|l|}{ Pengeluaran rumah tangga } \\
\hline$\geq \mathrm{UMR}$ & $16(66,67)$ & $8(33,33)$ & $24(100)$ & $0,26(0,086-0,82)$ & $\mathbf{0 , 0 1}$ \\
\hline$<\mathrm{UMR}$ & $116(88,55)$ & $15(11,45)$ & $131(100)$ & 1,00 & \\
\hline \multicolumn{6}{|c|}{$\begin{array}{l}\text { Frekuensi kunjungan ke Puskesmas/ } \\
\text { tenaga kesehatan selama hamil }\end{array}$} \\
\hline$\geq 4$ kali & $104(85,95)$ & $17(14,04)$ & $121(100)$ & $1,31(0,38-3,90)$ & 0,60 \\
\hline$<4$ kali & $28(82,35)$ & $6(17,65)$ & $34(100)$ & 1,00 & \\
\hline \multicolumn{6}{|c|}{ Tempat pemeriksaan kehamilan } \\
\hline Puskesmas/Pustu/RS & $123(88,49)$ & $16(11,51)$ & $139(100)$ & $5,98(1,62-20,71)$ & $\mathbf{0 , 0 0 1}$ \\
\hline Bidan & $9(56,25)$ & $7(43,75)$ & $16(100)$ & 1,00 & \\
\hline \multicolumn{6}{|l|}{ Tempat persalinan } \\
\hline Puskesmas/BPS/RB/RS & $110(88,00)$ & $15(12,00)$ & $125(100)$ & $2,67(0,86-7,67)$ & 0,08 \\
\hline Rumah sendiri/dukun & $22(73,33)$ & $8(26,67)$ & $30(100)$ & 1,00 & \\
\hline \multicolumn{6}{|l|}{ Dukungan suami } \\
\hline Suami & $101(88,60)$ & $13(11,40)$ & $114(100)$ & $2,51(0,88-6,86)$ & 0,04 \\
\hline Bukan suami & $31(75,61)$ & $10(24,39)$ & $41(100)$ & 1,00 & \\
\hline
\end{tabular}

Tabel 3. Hasil analisis variabel lain yang memiliki potensi hubungan dengan praktik pemberian ASI eksklusif

\begin{tabular}{|c|c|c|c|c|c|}
\hline \multirow[b]{2}{*}{ Variabel } & \multicolumn{2}{|c|}{ ASI eksklusif } & \multirow[b]{2}{*}{$\begin{array}{c}\text { Jumlah } \\
\text { n (\%) }\end{array}$} & \multirow[b]{2}{*}{ OR $(95 \% C I)$} & \multirow[b]{2}{*}{$\mathbf{p}$} \\
\hline & $\begin{array}{r}\text { Ya } \\
\text { n (\%) } \\
\end{array}$ & $\begin{array}{l}\text { Tidak } \\
\text { n (\%) }\end{array}$ & & & \\
\hline \multicolumn{6}{|l|}{ Kecamatan } \\
\hline Amanuban Barat & $67(77,01)$ & $20(22,99)$ & $87(100)$ & $0,15(0,03-0,56)$ & 0,001 \\
\hline Kie & $65(95,59)$ & $3(4,41)$ & $68(100)$ & 1,00 & \\
\hline \multicolumn{6}{|l|}{ Usia ibu (tahun) } \\
\hline $20-<35$ & $106(86,18)$ & $17(13,82)$ & $123(100)$ & $1,43(0,41-4,31)$ & 0,58 \\
\hline$<20$ dan $\geq 35$ & $26(81,25)$ & $6(18,75)$ & $32(100)$ & 1,00 & \\
\hline \multicolumn{6}{|l|}{ Usia suami (tahun) } \\
\hline $25-<40$ & $93(89,42)$ & $11(10,58)$ & $104(100)$ & $2,60(0,95-7,08)$ & $\mathbf{0 , 0 3}$ \\
\hline$<25$ dan $\geq 40$ & $39(76,47)$ & $12(23,53)$ & $51(100)$ & 1,00 & \\
\hline \multicolumn{6}{|l|}{ Pendidikan suami } \\
\hline Tinggi & $41(80,39)$ & $10(19,61)$ & $51(100)$ & $0,54(0,19-1,52)$ & 0,18 \\
\hline Rendah & $91(88,35)$ & $12(11,65)$ & $103(100)$ & 1,00 & \\
\hline \multicolumn{6}{|l|}{ Pekerjaan suami } \\
\hline Petani/peternak/nelayan/buruh tani & $104(86,67)$ & $16(13,33)$ & $120(100)$ & $0,72(0,24-2,46)$ & 0,58 \\
\hline Karyawanswasta/PNS/TNI/Polri/wiraswasta & $28(82,35)$ & $6(17,65)$ & $34(100)$ & 1,00 & \\
\hline \multicolumn{6}{|l|}{ Jenis kelamin bayi } \\
\hline Laki-laki & $67(50,76)$ & $65(49,24)$ & $132(100)$ & $1,34(0,50-3,67)$ & 0,52 \\
\hline Perempuan & $10(43,48)$ & $13(56,52)$ & $23(100)$ & 1,00 & \\
\hline \multicolumn{6}{|l|}{ Kategori usia bayi (bulan) } \\
\hline$<4$ & $82(89,13)$ & $10(10,87)$ & $92(100)$ & $2,13(0,79-5,84)$ & 0,09 \\
\hline$\geq 4$ & $50(79,37)$ & $13(20,63)$ & $63(100)$ & 1,00 & \\
\hline \multicolumn{6}{|l|}{ Jumlah anak dalam keluarga (orang) } \\
\hline$<3$ & $78(83,87)$ & $15(16,13)$ & $93(100)$ & $0,77(0,26-2,10)$ & 0,58 \\
\hline$\geq 3$ & $54(87,10)$ & $8(12,9)$ & $62(100)$ & 1,00 & \\
\hline
\end{tabular}









\section{BAHASAN}

\section{Hubungan faktor pendidikan ibu, pekerjaan ibu, dan pengeluaran rumah tangga dengan praktik pemberian ASI Eksklusif}

Studi ini menemukan bahwa pendidikan dan pekerjaan ibu tidak berhubungan dengan praktik pemberian ASI eksklusif yang sejalan dengan penelitian sebelumnya (17-19). Hal ini karena menyusui merupakan pilihan ibu yang tidak hanya melibatkan pendidikan ibu saja, tetapi juga melibatkan interaksi yang kompleks dari faktor sosial ekonomi, budaya, psikologis, dan lainlain (17). Pada penelitian ini, pendidikan hanya diukur dari jenjang pendidikan formal dan bukan berdasarkan pengetahuan yang dimiliki seseorang. Pendidikan formal bukan merupakan satu-satunya sumber pengetahuan seseorang. Seorang ibu dengan pendidikan formal yang rendah mungkin mempunyai pengetahuan yang tinggi tentang praktik pemberian ASI eksklusif yang diperoleh dari pendidikan informal seperti kursus, mengikuti pertemuan di lembaga-lembaga ibu menyusui informal, serta dari pengalaman. Tingkat pendidikan yang tinggi tidak menjamin ibu mempunyai pengetahuan tentang ASI lebih baik. Terkadang pendidikan yang semakin tinggi juga akan berdampak terhadap perubahan nilai-nilai sosial seperti adanya anggapan bahwa menyusui bayi dianggap tidak modern dan dapat mempengaruhi bentuk payudara ibu (20).

Hasil penelitian tidak sesuai dengan beberapa studi sebelumnya $(9,10,11,12)$ yang cenderung menemukan bahwa ibu yang berpendidikan formal tinggi (menyelesaikan sekolah menengah atas/ SMA) atau perguruan tinggi cenderung untuk menyusui lebih lama dibandingkan dengan ibu yang berpendidikan lebih rendah. Penelitian lain juga menemukan bahwa bayi yang dilahirkan dari orang tua yang berpendidikan rendah mempunyai kemungkinan lebih kecil untuk mendapatkan ASI eksklusif (21).

Penelitian sebelumnya juga menyebutkan bahwa pekerjaan tidak berhubungan dengan praktik pemberian ASI eksklusif dan pekerjaan bukan merupakan halangan untuk melaksanakan pemberian ASI eksklusif $(20,22)$. Dalam penelitian ini, pekerjaan tidak berhubungan dengan praktik pemberian ASI karena subjek sebagian besar $(87,7 \%)$ merupakan ibu rumah tangga yang tidak bekerja.

Berdasarkan hasil regresi logistik, ibu menyusui yang mempunyai pengeluaran rumah tangga lebih banyak dari UMR ( $\geq$ Rp 925.000) memiliki kemungkinan 3,7 kali lebih rendah untuk melakukan praktik pemberian ASI eksklusif (OR=0,27; 95\%CI: 0,09-0,84). Ibu dengan pengeluaran rumah tangga yang lebih rendah di Kecamatan Amanuban Barat dan Kie cenderung untuk mempunyai kemungkinan lebih besar untuk menyusui secara eksklusif. Pengeluaran rumah tangga yang tinggi biasanya identik dengan kepemilikan uang yang lebih banyak. Ibu yang mempunyai penghasilan tinggi, mempunyai kemungkinan lebih kecil untuk memberikan ASI eksklusif (20). Tingkat pengeluaran di atas UMR membuat ibu mempunyai daya beli yang tinggi dan mempunyai kemampuan secara ekonomi untuk membeli susu formula atau makananan pendamping ASI lainnya (19). Harga susu formula yang cenderung mahal akan membuat ibu dengan daya beli yang rendah lebih memilih memberikan ASI. Semakin meningkatnya sosial ekonomi keluarga akan menyebabkan terjadinya perubahan-perubahan dalam susunan makanan baik jenis maupun jumlahnya, termasuk pembelian makanan pendamping ASI.

Dalam penelitian ini, ibu yang mempunyai pengeluaran rumah tangga lebih tinggi dari UMR kemungkinan juga merupakan ibu bekerja yang persentasenya lebih sedikit dari ibu yang tidak bekerja. Ibu yang tidak bekerja cenderung mempunyai banyak waktu bersama dengan anaknya sehingga persentase menyusui eksklusif pada kedua kecamatan ini lebih tinggi pada ibu tidak bekerja. Suatu studi kualitatif (14) menemukan bahwa kesulitan terbesar dari menyusui adalah pada saat ibu kembali bekerja terutama saat anak belum berusia 6 bulan. Rendahnya persentase ASI eksklusif pada ibu yang bekerja kemungkinan karena saat bekerja, pengasuh mengombinasikan ASI dan susu formula atau minuman/ makanan lain untuk diberikan pada bayi. Hal tersebut juga dilakukan karena alasan kepraktisan sehingga ibu mertua, saudara, atau pengasuh bayi di rumah dapat merawat bayi mereka tanpa kesulitan. Studi di Kamboja juga melaporkan bahwa ibu-ibu yang sebelumnya bekerja di luar rumah baik part time maupun full time mempunyai 
risiko lebih tinggi untuk menghentikan pemberian ASI selama 6 bulan pertama (8). Hasil penelitian ini berbeda dengan penelitian sebelumnya yang menyebutkan bahwa semakin tinggi status ekonomi, maka semakin tinggi persentase ibu yang menyusui eksklusif $(12,23)$.

\section{Hubungan riwayat pemeriksaan kehamilan dengan praktik pemberian ASI eksklusif}

Berdasarkan analisis bivariat dan multivariat regresi logistik model 5 didapatkan hanya variabel tempat pemeriksaan kehamilan yang berhubungan secara signifikan dengan praktik pemberian ASI. Sebaliknya, tempat persalinan ibu secara statistik tidak berhubungan signifikan. Hasil penelitian ini sesuai dengan penelitian sebelumnya (8) yang menyatakan bahwa tidak ada hubungan signifikan antara tempat persalinan dengan praktik pemberian ASI eksklusif pada enam bulan pertama. Subjek umumnya berada di tempat persalinan selama satu hingga tiga hari saja sehingga waktu yang singkat tersebut membuat penjelasan mengenai menyusui eksklusif dari petugas kesehatan menjadi kurang dapat tersampaikan.

Frekuensi kunjungan ke pelayanan kesehatan saat hamil tidak berhubungan signifikan dengan praktik pemberian ASI eksklusif. Menurut hasil penelitian ini, sebagian besar ibu menyusui melakukan kunjungan ke puskesmas atau tenaga kesehatan selama hamil dengan frekuensi lebih dari empat kali kunjungan. Frekuensi atau kuantitas kunjungan ibu hamil sebenarnya tidak akan efektif apabila tidak disertai dengan kualitas kunjungan yang baik. Selain melakukan pemeriksaan kehamilan, seorang bidan atau dokter seharusnya memberikan edukasi kepada ibu hamil tentang bagaimana menyusui yang baik dan pentingnya menyusui terutama menyusui secara eksklusif. Penelitian sebelumnya (24) melaporkan bahwa pada saat pemeriksaan kehamilan, hampir semua ibu tidak mendapat penyuluhan intensif dari tenaga kesehatan tentang ASI eksklusif, perawatan payudara, ataupun posisi yang benar saat menyusui. Pada saat pemeriksaan kehamilan, hanya dilakukan pemeriksaan tekanan darah, palpasi, pemberian vitamin, dan pencatatan di buku Kesehatan Ibu dan Anak (KIA). Sebagian besar ibu menyatakan bahwa petugas kesehatan hanya mempunyai sedikit waktu dalam mendukung proses menyusui mereka (25).
Rendahnya tingkat pendidikan ibu dalam penelitian ini juga membuat kuantitas kunjungan menjadi tidak berpengaruh. Oleh karena itu, fokus pada edukasi tentang teknik menyusui yang benar baik pada kunjungan antenatal maupun postnatal diperlukan untuk mengurangi masalah menyusui pada ibu sehingga bisa meningkatkan durasi menyusui $(21,26)$. Namun demikian, kunjungan postnatal ini belum dapat dilakukan di tempat penelitian mengingat jarak serta sangat terbatasnya jumlah petugas kesehatan.

Hasil regresi logistik menunjukkan bahwa ibu menyusui yang melakukan pemeriksaan kehamilan di puskesmas, puskesmas pembantu, atau rumah sakit mempunyai kemungkinan 3,51 kali lebih tinggi untuk melakukan praktik pemberian ASI eksklusif saat bayinya lahir nanti daripada ibu yang melakukan pemeriksaan kehamilan pada bidan $(\mathrm{OR}=3,51 ; 95 \% \mathrm{CI}: 1,03-11,9)$. Sosialisasi program inisiasi menyusu dini (IMD) dan ASI eksklusif kepada bidan belum sepenuhnya berhasil kemungkinan disebabkan oleh beberapa faktor yaitu, 1) belum jelasnya pembagian tugas, peran, dan fungsi bidan, juga petunjuk teknis yang harus dilakukan bidan terutama bidan yang menjadi fasilitator dan tergabung dalam ikatan konselor ASI dalam rangka sosialisasi program IMD dan ASI eksklusif; 2) belum optimalnya fungsi dari agen sosialisasi (kepala puskesmas, Ikatan Bidan Indonesia/ IBI) dalam rangka sosialisasi program kepada bidan maupun kepada masyarakat secara umum; 3) belum adanya monitoring dan evaluasi sosialisasi implementasi program; dan 4) belum adanya sanksi dan reward yang jelas bagi bidan, atau bahkan karena kekurangtahuan bidan atas isi dan tujuan dari program tersebut (27).

\section{Hubungan dukungan suami dengan praktik pemberian ASI Eksklusif}

Pada analisis bivariat, dukungan suami mempunyai hubungan yang signifikan dengan praktik pemberian ASI eksklusif, tetapi setelah dimasukkan dalam analisis multivariat, diperoleh bahwa dukungan suami tidak berhubungan signifikan. Pada studi ini, walaupun mayoritas ibu didukung suami untuk menyusui secara eksklusif, tetapi kualitas dukungan tersebut tidak dapat digali, apakah ibu hanya sekedar menerima dukungan secara lisan atau dukungan yang disertai dengan tindakan 
suami dalam hal membantu istrinya agar dapat menyusui dengan baik.

Pada beberapa suami kadang ditemukan bahwa mereka tidak tahu dan khawatir tentang apa yang harus dilakukan pada istrinya setelah melahirkan (28). Hal tersebut mungkin dapat menjelaskan kenapa dukungan suami tidak berhubungan dengan praktik pemberian ASI eksklusif. Rendahnya pendidikan sebagian besar ibu dan suami di Kecamatan Amanuban Barat dan Kie juga membuat dukungan ini mungkin hanya sekedar dukungan lisan, tanpa pendidikan dan pengetahuan yang memadai, terutama tentang pemberian ASI eksklusif pada bayi. Hasil studi lain (29) juga menyatakan bahwa dukungan suami penting, tetapi membuat ibu menyusui itu mengerti tentang berbagai hal yang berhubungan dengan menyusui baik kesulitan dan manfaat yang akan diperoleh dari menyusi melalui pendidikan, nasihat, dan dukungan dari petugas kesehatan, keluarga, teman, maupun ibu menyusui lain merupakan hal yang terpenting untuk mencapaikan keberhasilan praktik pemberian ASI eksklusif.

\section{Hubungan variabel lain dengan praktik pemberian ASI Eksklusif}

Hasil analisis bivariat dan regresi logistik menunjukkan bahwa asal kecamatan berhubungan signifikan dengan praktik pemberian ASI eksklusif. Berdasarkan analisis regresi logistik pada model 5, ibu menyusui yang berasal dari Kecamatan Amanuban Barat mempunyai kemungkinan 5,3 kali lebih rendah untuk melakukan praktik pemberian ASI eksklusif kepada bayinya (OR=0,19; 95\%CI: 0,05-0,71). Hal ini sesuai dengan hasil hubungan signifikan pengeluran rumah tangga yang lebih tinggi dengan rendahnya praktik pemberian ASI eksklusif pada hasil sebelumnya.

Penduduk Kecamatan Amanuban Barat apabila dilihat dari keadaan lingkungan serta fasilitas yang ada, mempunyai pengeluaran yang lebih tinggi daripada penduduk di Kecamatan Kie. Industri yang lebih banyak, akses terhadap listrik, jalan beraspal, dan jarak lebih dekat dengan Ibu Kota Kabupaten membuat akses informasi dari media elektronik seperti radio dan televisi lebih mudah diakses oleh penduduk Amanuban Barat (30,31). Iklan berbagai macam produk termasuk produk-produk susu formula tentunya juga lebih banyak mempengaruhi penduduk Amanuban Barat daripada Kie, sehingga kemungkinan dapat mempengaruhi keputusan ibu dalam memberikan ASI eksklusif. Selain itu, arus modernisasi di Kecamatan Amanuban Barat membuat masyarakat kurang peduli tentang pentingnya ASI eksklusif karena pengaruh perubahan nilai sosial budaya yang terdapat di daerah perkotaan menyebabkan pemberian ASI pada bayi dianggap tidak modern (10,32). Praktik ASI eksklusif lebih banyak ditemukan di pedesaan dibandingkan perkotaan karena sebagian besar bayi di perkotaan telah mengenal susu formula $(33,34)$. Keberadaan kebiasaan menyusui secara tradisional (tanpa botol susu dan susu formula) yang ada dalam suatu populasi kemungkinan akan berubah karena adanya kontak dengan dunia luar yang menyebabkan perubahan ekonomi, nilai, dan kepercayaan (35).

\section{SIMPULAN DAN SARAN}

Faktor pengeluaran rumah tangga, tempat pemeriksaan kehamilan, dan asal kecamatan berhubungan dengan praktik pemberian ASI eksklusif. Sementara itu, faktor pendidikan ibu, pekerjaan ibu, tempat persalinan, frekuensi kunjungan ke puskesmas/tenaga kesehatan, dan dukungan suami tidak berhubungan dengan praktik pemberian ASI eksklusif. Perlu edukasi dan promosi yang melibatkan semua aspek mengenai pentingnya pemberian ASI eksklusif terutama pada ibu menyusui dengan pengeluaran rumah tangga yang tinggi (lebih dari UMR) serta pada petugas kesehatan di tempat pemeriksaan kehamilan khususnya di Kecamatan Amanuban Barat.

\section{Pernyataan konflik kepentingan}

Penulis menyatakan tidak ada konflik kepentingan dalam penelitian ini.

\section{RUJUKAN}

1. WHO Collaborative Study Team on the Role of Breastfeeding on the Prevention of Infant Mortality. Effect of breastfeeding on infant and child mortality due to infectious diseases in less developed countries: a pooled analysis. Lancet. 2000;355(9202):451-5.

2. Kramer M, Kakuma R. The optimal duration of exclusive breastfeeding: a systematic review. Adv Exp Med Biol. 2004;554:63-77. doi: 10.1007/978-1-4757-4242-8_7 
3. Uruakpa FO, Ismond MAH, Akobundu ENT. Colostrum and its benefits: a review. Nutrition Research. 2002;22(6):75567. doi: 10.1016/S0271-5317(02)00373-1

4. Horta BL, Bahl R, Martines JC, Victora CG. Evidence on the long-term effects of breastfeeding: systematic reviews and meta-analyses. [series online] 2007 [2013 Maret 27]. Available from: URL: http://whqlibdoc.who. int/publications/2007/9789241595230_eng.pdf

5. American Dietetic Association. Position of the American Dietetic Association: promoting and supporting breastfeeding. J Am Diet Assoc. 2009;109(11):1926-42. doi: 10.1016/j.jada.2009.09.018

6. Kementerian Kesehatan RI. Riset Kesehatan Dasar 2018. [series online] 2018 [cited 6 Januari 2020]. Available from: URL: https://www.depkes.go.id

7. Dinas Kesehatan Kabupaten Timor Tengah Selatan. Profil Dinas Kesehatan Kabupaten Timor Tengah Selatan [series online] 2017 [cited 6 Januari 2020]. Available from: URL: www.depkes.go.id

8. Sasaki Y, Ali M, Kakimoto K, Saroeun O, Kanal K, Kuroiwa C. Predictors of exclusive breast-feeding in early infancy: a survey report from Phnom Penh, Cambodia. J Pediatr Nurs. 2010;25(6):463-9. doi: 10.1016/j. pedn.2009.04.010

9. Roig AO, Martínez MR, García JC, Hoyos SP, Navidad GL, González RGDL, et al. Factors associated to breastfeeding cessation before 6 months. Rev. Latino-Am. Enfermagem. 2010;18(3):373-80. doi: 10.1590/S010411692010000300012

10. Abada TS, Trovato F, Lalu N. Determinants of breastfeeding in the Philippines: a survival analysis. Soc Sci Med. 2001;52(1):71-81. doi: 10.1016/s0277-9536(00)00123-4

11. Hornbeak DM, Dirani M, Sham WK, Li J, Young TL, Saw $\mathrm{SM}$, et al. Emerging trends in breastfeeding practices in Singaporean Chinese women: finding from a populationbased study. Ann Acad Med Singapore. 2010;39(2):88-94.

12. Khoury AJ, Moazzem SW, Jarjoura CM, Carothers C, Hinton A. Breast-feeding initiation in low-income women: role of attitudes, support, and perceived control. Women's Health Issues. 2005;15(2):64-72. doi: 10.1016/j. whi.2004.09.003

13. Kools EJ, Thijs C, Kester ADM, Vries HD. The motivational determinants of breast-feeding: predictors for the continuation of breast-feeding. Prev Med. 2006;43(5):394401. doi: 10.1016/j.ypmed.2006.03.012

14. Lundberg PC, Thu TTN. Breast-feeding attitudes and practices among Vietnamese mothers in Ho Chi Minh City. Midwifery. 2012;28(2):252-7. doi: 10.1016/j. midw.2011.02.012

15. Agho KE, Dibley MJ, Odiase JI, Ogbonmwan SM. Determinants of exclusive breastfeeding in Nigeria. BMC
Pregnancy and Childbirth. 2011;11(2). doi: 10.1186/14712393-11-2

16. Alma Ata Centre for Healthy Life and Food (ACHEAF), United Nation Food World Program (UNWFP). Final report analisis tentang perilaku dan praktik konsumsi makanan/diet pada anak di bawah 5 tahun, anak sekolah, ibu hamil, dan ibu menyusui di Kabupaten Timor Tengah Selatan, Provinsi NTT, Indonesia. Yogyakarta: ACHEAF; 2013.

17. Chudasama RK, Amin CD, Parikh YN. Prevalence of exclusive breastfeeding and its determinants in first 6 months of life: a prospective study. Online J Health Allied Scs. 2019;8(1):3.

18. Dashti M, Scott JA, Edwards CA, Al-Sughayer M. Determinant of breastfeeding initiation among mothers in Kuwait. Int Breastfeed J. 2010;5:7. doi: 10.1186/17464358-5-7

19. Purnamawati S. Faktor-faktor yang berhubungan dengan pola pemberian ASI pada bayi usia empat bulan (analisis data Susenas 2001). Media Litbang Kesehatan. 2003;8(3):29-37.

20. Sriningsih I. Faktor demografi, pengetahuan ibu tentang air susu ibu dan pemberian ASI eksklusif. KEMAS: Jurnal Kesehatan Masyarakat. 2011;6(2):100-6.

21. Srivastava NM, Awasthi S. Breastfeeding practices for newborns among urban poor in Lucknow, northern India: a prospective follow-up study. Clinical Epidemiology and Global Health. 2014;2(2):66-74.

22. Abuidhail J, Al-Modallal H, Yousif R, Almresi N. Exclusive breast feeding (EBF) in Jordan: prevalence, duration, practices, and barriers. Midwifery. 2014;30(3):331-7. doi: 10.1016/j.midw.2013.01.005

23. Apostolakis-Kyrus K, Valentine C, DeFranco E. Factors associated with breastfeeding initiation in adolescent mothers. J Pediatr. 2013;163(5):1489-94. doi: 10.1016/j. jpeds.2013.06.027

24. Noer ER, Muis SF, Aruben R. Praktik inisiasi menyusu dini dan pemberian ASI eksklusif studi kualitatif pada dua puskesmas, Kota Semarang. Media Medika Indonesia. 2011;45(3):144-50.

25. Barclay L, Longman J, Schmied V, Sheehan A, Rolfe M, Fenwick J, et al. The professionalising of breastfeedingwhere are we a decade on?. Midwifery. 2012;28(3):281-90. doi: 10.1016/j.midw.2011.12.011

26. Coutinho SC, de Lira PIC, de Carvalho Lima M, Ashworth A. Comparison of the effect of two systems for the promotion of exclusive breastfeeding. Lancet. 2005;366(9491):109100. doi: 10.1016/S0140-6736(05)67421-1

27. Aprilia Y. Analisis sosialisasi program inisiasi menyusu dini dan ASI eksklusif kepada bidan di Kabupaten Klaten 
[Tesis]. Semarang: Program Studi Magister Ilmu Kesehatan Masyarakat Universitas Diponegoro Semarang; 2010.

28. Meedya S, FahyK, Kable A. Factors that positively influence breastfeeding duration to 6 months: a literature review. Women Birth. 2010;23(4):135-45. doi: 10.1016/j. wombi.2010.02.002

29. Powell R, Davis M, Anderson AK. A qualitative look into mother's breastfeeding experiences. Journal of Neonatal Nursing. 2014;20(6):259-65. doi: 10.1016/j. jnn.2014.04.001

30. Badan Pusat Statistik Kabupaten Timor Tengah Selatan. Amanuban Barat dalam angka 2014. [series online] 2014 [cited 23 Januari 2015]. Available from: URL: http://timortengahselatankab.bps.go.id/index. php?hal=publikasi_detil\&id $=150$

31. Badan Pusat Statistik Kabupaten Timor Tengah Selatan. Kecamatan Kie dalam Angka 2014. [series online] 2014 [cited 23 Januari 2015]. Available from:
URL: http://timortengahselatankab.bps.go.id/index. php?hal=publikasi_detil\&id=163

32. Sarbini D, Hidayati L. Hubungan antara tingkat pendapatan keluarga dan pendidikan ibu dengan pemberian ASI eksklusif di Kecamatan Jebres Kotamadya Surakarta. Jurnal Kesehatan.2008;1(2):115-22.

33. Rachmadewi A, Khomsan A. Pengetahuan, sikap, dan praktek ASI ekslusif serta status gizi bayi usia 4-12 bulan di pedesaan dan perkotaan. Jurnal Gizi dan Pangan. 2009;4(2):83-90. doi: 10.25182/jgp.2009.4.2.83-92

34. Dickson I. The association between breastfeeding practices in Mongolia and geographical location of the mother and child. [Thesis]. Washington: Master of Public Health, University of Washington; 2012.

35. Veile A, Martin M, McAllister L, Gurven M. Modernization is associated with intensive breastfeeding patterns in the Bolivian Amazon. Soc Sci Med. 2014;100:148-58. doi: 10.1016/j.socscimed.2013.10.034 